\title{
Public Facilities Management: Moving Toward Crisis
}

\author{
By \\ Rebecca Smith, University of South Florida
}

T he single greatest asset value of most public entities is their land holdings and facilities. Most would consider it to be unforgivable for any leader to overlook the needs of their greatest asset, yet it happens. Deferred maintenance is a mounting problem that has become insurmountable in some cases. Why is this the case and how did we get here?

Deferred maintenance has been a snowball growing ever larger since WWII, and still there are too many public facilities owners who do not have the means (both budgetary and process) to efficiently and effectively manage their facilities' needs. The high cost of failure ranges from the increased cost of repairs to the increased liability due to injury. Further impact includes shortening of the intended useful life of the building.

For example, on the national level it was estimated that our infrastructure (roads, rails, waterworks, and bridges) had a shortfall of \$1.6 trillion as of 2007. Then, additional information in 2008-9, indicated our nation's public school facilities alone required $\$ 127$ billion just to raise them to a level of "good condition," and \$542 billion if alterations and scheduled renewals of existing facilities were included. These costs are staggering; however, when deferred, they rise exponentially and at the same time increase the potential for liability as the facilities continue to deteriorate.

Although unbelievable, this lack of attention to facilities is more common than not. It can be argued that it is not always an intentional deferral due to the lack of funds. In fact, in many cases, deferral can be attributed to the lack of
Facilities management has become increasingly challenging over the years as facilities expand and the cost of construction increases. Deferred maintenance is a mounting problem that is insurmountable in some cases. Why is this the case and how did we get here? a structured facilities program, or even the lack of a true understanding of the facilities' needs.

This research will address the following questions:

1) Why is deferred maintenance allowed to occur?

2) How has deferred maintenance become a "standard practice" given the developing insurmountable backlog, higher costs of maintenance, greater risk and liability, and the reduced useful life of the facility?

3) Is there hope for redirecting an asset portfolio that has a failing facilities management plan and is heading toward crisis?

Keywords: Lack of Funding, Growth Cycle, Productivity, Crisis, Asset, Facilities Management, Maintenance Budget, Priority, Communication, Knowledge, Strategic Plan.

Copyright $\odot$ 2017, Rebecca Smith. This article is published under a Creative Commons BY-NC license. Permission is granted to copy and distribute this article for non-commercial purposes, in both printed and electronic formats 


\section{Introduction}

Among the many topics that warrant research and study, facilities management and maintenance is near the top of the list titled: Who cares? Engaging a person in a discussion about the challenges that face the facilities management industry is somewhat amusing as you watch their eyes begin looking around the room. They glance at their watch and, at the first opportunity, they shift subjects or worse yet, excuse themselves altogether. They have no idea how these issues impact their life and therefore, have no interest in hearing about them. But, alas, the same conversation held with the owner of an asset portfolio elicits a different level of interest.

This research is pointed toward those who are the owners of high-valued, facilities asset portfolios. Yes, you, the tax-paying general public. This is your asset portfolio being awkwardly managed to the detriment of your interests. This study is intended to bring to light the dim subject of facilities management and maintenance in hopes that more emphasis is placed on properly maintaining your assets with efficiency, and achieving the effective results for which you are paying. Successful facilities management results in lower cost of ownership, less exposure to liability, and a longer useful life of your investments.

Given a refreshed perspective of the importance of facilities management and maintenance, it becomes imperative that we identify those contributing issues that impact the success or failure of the intended mission. As a whole, the overwhelming nature of the process contributes to the lack of action and denies the opportunity for rehabilitation. The sum of the problem must be broken into parts to affect change, and provide opportunity to create a more efficient and effective facilities management and maintenance program.

\section{Methodology}

Addressing the research question, we conducted a literature review on the challenge of deferred maintenance within the business of public facilities management. Our approach for the literature review incorporated the following sources: academic databases (Ebsco Business Search Premier), the business press and building industry trade to gain insight from an industry perspective, published government studies, Google and Google Scholar, and references in articles cited. We used keywords in various combinations to include: facilities management, deferred maintenance, pent up maintenance demand, school funding for maintenance, facilities budget, and infrastructure funding. The results of the search formed the basis of this study. Most of the research found was in the business press, industry publications, and government studies (see Tables 1 through 6).

Table 1: Funding decision made by those who lack expertise on issues related to facilities management

\begin{tabular}{|c|c|}
\hline Source & Findings \\
\hline $\begin{array}{l}\text { Westerling, D., \& Poftak, S. } \\
\text { (2007). Our legacy of ne- } \\
\text { glect: The Longfellow Bridge } \\
\text { and the cost of deferred } \\
\text { maintenance. White Paper, } \\
\text { 40, 1-36. }\end{array}$ & $\begin{array}{l}\text { - Conclusions: } \\
\text { a) Stop building new assets without first examining the budget for } \\
\text { life-cycle costs, including regular maintenance. } \\
\text { b) Measure the condition, account for the maintenance needs, and } \\
\text { adopt a financial reporting standard that emphasizes asset man- } \\
\text { agement. } \\
\text { c) Budget for maintenance equal to two percent of asset replacement } \\
\text { value and create a reserve fund. } \\
\text { d) Execute improved maintenance practices including mandating } \\
\text { the use of asset management systems. } \\
\text { e) Reward managers and department heads with additional funding } \\
\text { if they take a responsible approach to asset management (page 2). }\end{array}$ \\
\hline $\begin{array}{l}\text { Postal, L. (2012, January 13). } \\
\text { Statewide shortfall likely to } \\
\text { halt school building plans. } \\
\text { Orlando Sentinel. }\end{array}$ & $\begin{array}{l}\text { - "It has become necessary for difficult decisions to be made on which } \\
\text { projects may be funded and which must be discontinued at this point } \\
\text { in time," Gov. Rick Scott said in response to the } \$ 250 \text { million shortfall } \\
\text { in funding. }\end{array}$ \\
\hline
\end{tabular}


Table 1 (Continued): Funding decision made by those who lack expertise on issues related to facilities management

\begin{tabular}{|c|c|}
\hline Source & Findings \\
\hline $\begin{array}{l}\text { Payton-Jones, K. (2014). A } \\
\text { matter of time: Perspectives } \\
\text { on deferred maintenance. } \\
\text { American School and Univer- } \\
\text { sity. }\end{array}$ & $\begin{array}{l}\text { - "In K-12 schools, there is a direct correlation between the condition } \\
\text { and cleanliness of the school and grades, attitudes, absenteeism" (page } \\
\text { 14). } \\
\text { - The national institute of building sciences did a study that shows poor } \\
\text { building conditions definitely impact teaching and learning (page 14). } \\
\text { "At the end of the day people need to understand what happens when } \\
\text { you reduce the budget. How quickly do the buildings deteriorate? } \\
\text { How many more days are people missing because they are getting } \\
\text { sick?... What is the cost for that" (page 15)? }\end{array}$ \\
\hline $\begin{array}{l}\text { Filardo, M. (2016). State of } \\
\text { our schools: America's K-12 } \\
\text { facilities 2016. Washington, } \\
\text { DC: 21st Century School } \\
\text { Fund. }\end{array}$ & $\begin{array}{l}\text { - At its heart, school facility quality is a matter of equity, and responsi- } \\
\text { ble planning for the future requires that we have better information } \\
\text { about the condition of our nation's schools (page } 2 \text { ). } \\
\text { A large and growing body of evidence demonstrates that school facili- } \\
\text { ties have a direct impact on student learning, student and staff health, } \\
\text { and school finances. Despite this too many students attend school } \\
\text { facilities that fall short of providing } 21^{\text {st }} \text { century learning environ- } \\
\text { ments because essential maintenance and capital improvements are } \\
\text { underfunded (page } 3 \text { ). } \\
\text { - Are districts and states investing the capital funds necessary to ensure } \\
\text { their public schools are educationally appropriate, energy efficient, } \\
\text { and environmentally responsible (page 3)? } \\
\text { Do states and districts have adequate operating funds for cleaning, } \\
\text { maintenance, and repairs to ensure buildings and grounds are healthy } \\
\text { and safe (page 3)? } \\
\text { Are states and the federal government doing enough to ensure equity } \\
\text { in education, so all students have access to healthy and safe school } \\
\text { facilities that support learning (page } 3 \text { )? } \\
\text { This report identifies four key strategies for addressing the structural } \\
\text { deficits in K-12 public education infrastructure (page } 4 \text { ). } \\
\text { Recommendations: } \\
\text { - First, understand current facilities conditions. } \\
\text { - Second, engage communities in planning for adequate and equitable } \\
\text { 21 century facilities. } \\
\text { Third, find and pilot new innovative sources of public funding. } \\
\text { - Finally, leverage public and private resources. }\end{array}$ \\
\hline $\begin{array}{l}\text { Millan, N. (2016). Rising star } \\
\text { in Texas. Building Operating } \\
\text { Management, 22-27. }\end{array}$ & $\begin{array}{l}\text { - What would you do with a million dollars?... He used the resources } \\
\text { to perform an exhaustive assessment of every facility in the portfolio } \\
\text { and create a facility condition index rating (page } 22 \text { ). } \\
\text { - The first priority was getting a handle on the situation. } \\
\text { - The city was mired in } \$ 450 \text { million backlog of deferred maintenance } \\
\text { (page 24). } \\
\text { "...the ballpark was } 96 \text { percent reactive. The industry best practice is } \\
80 \text { percent predictive and } 20 \text { percent reactive.... I wanted to become } \\
\text { more intentional and strategic in how we do our work." Using the } \\
\text { facility assessment, his team crafted a strategic facility plan (page 24). } \\
\text { - Starting with the most critical needs, the department has been me- } \\
\text { thodically addressing the maintenance backlog and incrementally } \\
\text { increasing its percentage of predictive work (page } 24 \text { ). } \\
\text { Working closely with the mayor and a key council member, Minnix } \\
\text { helped to create a line item in the city's budget to address mainte- } \\
\text { nance, renewal, and repair (MRR) of municipal buildings (page 24). } \\
\text { Minnix values the MRR fund for how it symbolizes the city's commit- } \\
\text { ment to improving its municipal structures (page 25). }\end{array}$ \\
\hline
\end{tabular}


Table 1 (Continued): Funding decision made by those who lack expertise on issues related to facilities management

\begin{tabular}{|l|l|}
\hline \multicolumn{1}{|c|}{ Source } & \multicolumn{1}{c|}{ Findings } \\
\hline $\begin{array}{l}\text { Millan, N. (2016). Rising star } \\
\text { in Texas. Building Operating } \\
\begin{array}{l}\text { Management, 22-27. (Con- } \\
\text { tinued) }\end{array}\end{array}$ & $\begin{array}{l}\text { The nature of municipal facilities management presents many chal- } \\
\text { lenges besides the simple fact that everything one does is up for public } \\
\text { scrutiny (page 25). }\end{array}$ \\
$\begin{array}{l}\text { One challenge is the influence of politics (page 25). } \\
\text { We have to spend a lot of time and resources in trying to get buy-in, } \\
\text { so that we are all pulling in the same direction (page 25). }\end{array}$ \\
$\begin{array}{l}\text { Once you get down to the Citys infrastructure, items like roads used } \\
\text { by millions of people every day are higher on the list than the city } \\
\text { buildings (page 25). }\end{array}$ \\
\hline
\end{tabular}

Table 2: Lack of understanding of immediate cost (lowest) versus deferred cost (higher)

\begin{tabular}{|c|c|}
\hline Source & Findings \\
\hline $\begin{array}{l}\text { Westerling, D., \& Poftak, S. } \\
\text { (2007). Our legacy of ne- } \\
\text { glect: The Longfellow Bridge } \\
\text { and the cost of deferred } \\
\text { maintenance. White Paper, } \\
40,1-36 .\end{array}$ & $\begin{array}{l}\text { - For any asset, there is a } 40 \% \text { drop in quality over } 75 \% \text { of its lifetime, } \\
\text { which is followed by a more precipitous drop in the final quarter in the } \\
\text { asset's life (page 13). } \\
\text { Deferred maintenance is the compounded effect of deferring mainte- } \\
\text { nance from one year to the next. The cost of deferred maintenance in } \\
\text { year one will increase significantly in every subsequent year (page 13). } \\
\text { - DeSitter's law (law of fives) estimates that if maintenance is not per- } \\
\text { formed, then repairs equaling five times the maintenance costs are } \\
\text { required (page 13). } \\
\text { A model was created that showed how sustained investment would } \\
\text { have reduced the overall cost of owning the Longfellow Bridge for the } \\
\text { past hundred years (page 13). } \\
\text { No matter which entity is responsible, every state asset suffers from } \\
\text { the same treatment. We fail to adequately budget for maintenance; } \\
\text { even worse, we actively create perverse incentives that discourage state } \\
\text { managers from maintaining state assets. } \\
\text { Any maintenance spending from an agency's operating budget reduces } \\
\text { funds available for programs. The postponement of routine mainte- } \\
\text { nance maximizes operating funds available in the current year, but } \\
\text { also hastens the failure of capital assets. The eventual failure of the } \\
\text { assets results in an emergency disbursement of capital funds, which } \\
\text { are under the Division of Capital Asset Management's (DCAM) con- } \\
\text { trol, and do not impact the agency's operating budget. Thus, managers } \\
\text { who spend money on maintenance are in effect penalized for trying to } \\
\text { maintain their assets. }\end{array}$ \\
\hline $\begin{array}{l}\text { Lawrence, B. K. (2003). Save } \\
\text { a penny, lose a school: The } \\
\text { real cost of deferred main- } \\
\text { tenance. Rural Trust Policy } \\
\text { Brief Series on Rural Educa- } \\
\text { tion }\end{array}$ & $\begin{array}{l}\text { - Preventative routine maintenance can extend the life of any facility } \\
\text { and, therefore, is a good investment. } \\
\text { - Deferring maintenance is very expensive. } \\
\text { - Deferring maintenance reduces air quality, causes breakdowns in } \\
\text { infrastructure and mechanics, and creates higher energy consumption, } \\
\text { which leaves even less money available for maintenance (page 9). }\end{array}$ \\
\hline $\begin{array}{l}\text { Filardo, M. (2016). State of } \\
\text { our schools: America's K-12 } \\
\text { facilities 2016. Washington, } \\
\text { DC: 21st Century School } \\
\text { Fund. }\end{array}$ & $\begin{array}{l}\text { - Underspending on routine and preventative maintenance in the short } \\
\text { term leads to much higher building costs in the long term (page 7). } \\
\text { Due to a history of national underinvestment in school facilities, } \\
\text { school districts have struggled to keep up with basic maintenance and } \\
\text { repairs, renewals, and alterations. The delay of these important re- } \\
\text { sponsibilities has led to a backlog of critical projects in many districts, } \\
\text { which can trigger emergency repairs and higher expenses (page 12). }\end{array}$ \\
\hline
\end{tabular}


Table 2 (Continued): Lack of understanding of immediate cost (lowest) versus deferred cost (higher)

\begin{tabular}{|l|l|}
\hline \multicolumn{1}{|c|}{ Source } & \multicolumn{1}{c|}{ Findings } \\
\hline $\begin{array}{l}\text { Filardo, M. (2016). State of } \\
\text { our schools: America's K-12 } \\
\text { facilities 2016. Washington, } \\
\text { DC: 21st Century School } \\
\text { Fund. (Continued) }\end{array}$ & $\begin{array}{l}\text { If school districts do not renew their building systems and compo- } \\
\text { nents on a timely schedule, then deferred maintenance will accumu- } \\
\text { late, costs for annual maintenance and repairs will rise, and poor basic } \\
\text { building conditions will compromise the benefits of alterations for } \\
\text { program or capacity adjustments (page 22). }\end{array}$ \\
\hline $\begin{array}{l}\text { Carlson, S. (2008). As cam- } \\
\text { puses crumble, budgets are } \\
\text { crunched. The Chronicle of } \\
\text { Higher Education, 37(15), } \\
\text { A1. }\end{array}$ & $\begin{array}{l}\text { If colleges can't support their existing buildings, yet continue adding } \\
\text { new ones, Carlson says, they risk operating in what the facilities indus- } \\
\text { try calls, "run to failure mode;" in other words, running the building } \\
\text { into the ground (page 2). } \\
\text { Patching a water line might cost \$10,000 but replacing that same line } \\
\text { would cost \$900,000--the motivation to patch is driven by the realities } \\
\text { of the budget (page 2). }\end{array}$ \\
\hline $\begin{array}{l}\text { Payton-Jones, K. (2014). A } \\
\text { matter of time: Perspectives } \\
\text { on deferred maintenance. } \\
\text { American School and Uni- } \\
\text { versity. }\end{array}$ & $\begin{array}{l}\text { Seventy percent of maintenance costs should be preventative or } \\
\text { planned maintenance, and 30 percent of maintenance costs should be } \\
\text { emergency maintenance. Unfortunately, in most cases the opposite is } \\
\text { true (page 13). } \\
\text { "People often use the phrase 'pay me now or pay me later. But when it } \\
\text { comes to deferred maintenance it needs to be changed to pay me now } \\
\text { or pay me more later" (page 15). }\end{array}$ \\
\hline
\end{tabular}

Table 3: Lack of communication and clear understanding between all responsible parties from funding to fixing

\begin{tabular}{|l|l|}
\hline Source & Findings \\
\hline $\begin{array}{l}\text { Westerling, D., \& Poftak, } \\
\text { S. (2007). Our legacy of } \\
\text { neglect: The Longfellow } \\
\text { Bridge and the cost of de- } \\
\text { ferred maintenance. White } \\
\text { Paper, 40,1-36. }\end{array}$ & $\begin{array}{l}\text { We lack a centralized system to comprehensively manage our assets. } \\
\text { Our financial reporting system lacks procedures for condition assess- } \\
\text { ment of assets (page 29). }\end{array}$ \\
\hline $\begin{array}{l}\text { Carlson, S. (2008). As cam- } \\
\text { puses crumble, budgets are } \\
\text { crunched. The Chronicle of } \\
\begin{array}{l}\text { Higher Education, 37(15), } \\
\text { Al. }\end{array}\end{array}$ & $\begin{array}{l}\text { The more specific, or transparent, you can be about stating your needs, } \\
\text { whether it be to a board of regents or a state department of adminis- } \\
\text { tration, the more effective you will be at getting the funds you need } \\
\text { (page 4). }\end{array}$ \\
\hline $\begin{array}{l}\text { Payton-Jones, K. (2014). A } \\
\text { matter of time: Perspectives } \\
\text { on deferred maintenance. } \\
\text { American School and Uni- } \\
\text { versity. }\end{array}$ & $\begin{array}{l}\text { Understanding the cost of deferred maintenance and being able to } \\
\text { articulate the cost to the boards and committees that will take the next } \\
\text { steps to obtain taxes, state help, and/or fundraising is essential for } \\
\text { facilities administrators (page 14). }\end{array}$ \\
\hline $\begin{array}{l}\text { Hunter, R. C. (2009). The } \\
\text { public school infrastruc- } \\
\text { ture problem: Deteriorat- } \\
\text { ing buildings and deferred } \\
\text { maintenance. School Busi- } \\
\text { ness Affairs, 75(2), 10-14. }\end{array}$ & $\begin{array}{l}\text { "After each inspection, I completed a school data sheet and developed } \\
\text { photo albums illustrating the condition of each school building. The } \\
\text { photographs became a valuable tool in presenting evidence to the fed- } \\
\text { eral court about the condition of each school building during testimo- } \\
\text { ny" (page 13). }\end{array}$ \\
\hline
\end{tabular}


Table 3 (Continued): Lack of communication and clear understanding between all responsible parties from funding to fixing

\begin{tabular}{|c|c|}
\hline Source & Findings \\
\hline $\begin{array}{l}\text { Millan, N. (2016). Rising } \\
\text { star in Texas. Building Op- } \\
\text { erating Management, 22-27. }\end{array}$ & $\begin{array}{l}\text { - "I have to continually be able to paint that picture., Minnix says. } \\
\text { "I have to be really in tune to my people, but also be in tune to the } \\
\text { political framework that runs this city and be able to share with them } \\
\text { what exactly is going on. I have to stay consistent with a message, and I } \\
\text { have to do it on a regular basis. It's not a one-time, 'I told you' I have to } \\
\text { continue playing my music on a regular basis and they'll start to listen" } \\
\text { (page 25). } \\
\text { - Besides being in tune with the top levels of city government, Min- } \\
\text { nix says he makes it a point to connect with the leaders of individual } \\
\text { departments from the parks to the libraries to the head of the animal } \\
\text { shelter, to understand their day-to-day needs. "You really need to un- } \\
\text { derstand the operational needs of everyone you serve" (page 25). } \\
\text { - One of the first and best things he brought to the department is collab- } \\
\text { orative teamwork (page 27). } \\
\text { He started weekly strategy meetings and reorganized the General } \\
\text { Services Dept. to be more collaborative, creating smaller individual } \\
\text { workstations with lower partitions heights and greater communal } \\
\text { collaborative space (page 27). } \\
\text { "My job is not to do their job. When the leader leaves to do the work, } \\
\text { there is nobody up front leading" (page 27). } \\
\text { Minnix says he can give his team autonomy, and he keeps them ac- } \\
\text { countable for that autonomy (page 27). } \\
\text { "When my guys connect to how important it is that the rollup door } \\
\text { opens at a fire station, not because it's an operating door and should } \\
\text { work, but because they're trying to save lives, my guys work differently } \\
\text { (page 27)" } \\
\text { "Because they're connected to this something that's greater than a } \\
\text { wrench and electrical wires. I think our role as leaders has to be to be } \\
\text { able to do that whole process. You have to be in tune to your folks, you } \\
\text { have to help them develop this mastery. You have to connect them to } \\
\text { autonomy and accountability. And you have to connect them to their } \\
\text { passion and purpose" (page 27). }\end{array}$ \\
\hline $\begin{array}{l}\text { Filardo, M. (2016). State } \\
\text { of our schools: America's } \\
\text { K-12 facilities 2016. Wash- } \\
\text { ington, DC: 21st Century } \\
\text { School Fund. }\end{array}$ & $\begin{array}{l}\text { - The district must acquire and build facilities and grounds, renew or } \\
\text { replace building systems and components over time, alter facilities } \\
\text { to support evolving educational requirements, and manage deferred } \\
\text { maintenance backlogs (communicating expectation to leadership). } \\
\text { - Good practice calls for enhancing these basic building standards to } \\
\text { also extend to the responsibilities of states and districts to reduce the } \\
\text { accumulation of deferred maintenance in school buildings, and deliver } \\
\text { facilities that support changing instructional methods, technologies, } \\
\text { and community needs (page 22). }\end{array}$ \\
\hline
\end{tabular}

Table 4: Far reaching negative impacts due to excessive deferred maintenance

\begin{tabular}{|l|l|}
\hline \multicolumn{1}{|c|}{ Source } & \multicolumn{1}{c|}{ Findings } \\
\hline $\begin{array}{l}\text { Payton-Jones, K. (2014). A } \\
\text { matter of time: Perspectives } \\
\text { on deferred maintenance. } \\
\begin{array}{l}\text { American School and Uni- } \\
\text { versity. }\end{array}\end{array}$ & $\begin{array}{l}\text { There is a direct correlation between the condition and cleanliness of } \\
\text { the school and grades, attitudes, and absenteeism (page15). } \\
\text { The National Institute of Building Sciences did a study that shows that } \\
\text { poor building conditions definitely negatively impact teaching and } \\
\text { learning. }\end{array}$ \\
\hline
\end{tabular}


Table 4 (Continued): Far reaching negative impacts due to excessive deferred maintenance

\begin{tabular}{|l|l|c|}
\hline \multicolumn{1}{|c|}{ Source } & Findings \\
\hline $\begin{array}{l}\text { Lawrence, B. K. (2003). Save } \\
\text { a penny, lose a school: The } \\
\text { real cost of deferred main- } \\
\text { tenance. Rural Trust Policy } \\
\text { Brief Series on Rural Educa- } \\
\text { tion }\end{array}$ & $\begin{array}{l}\text { Practice recommendations that directly affect maintenance } \\
\text { Require regular annual inspection by a certified engineer of conditions } \\
\text { in school facilities as they affect health and safety }\end{array}$ \\
Require state assessment of facilities by an independent evaluator ev- \\
ery five years (or whenever a major change to the facility is proposed) \\
Not only does deferred maintenance affect the health and safety of \\
those who use the facility as well as the performance of teachers and \\
students, it also threatens the school itself (page 16). \\
Deferring maintenance reduces air quality, causes breakdowns in \\
infrastructure and mechanics, and causes higher energy consumption, \\
which leaves even less money available for maintenance. The condition \\
of poorly maintained facilities can affect the health and safety of chil- \\
dren and adults who use them, as well as their morale and academic \\
performance. \\
a) Impacts on staff and student morale \\
b) Effect of poor conditions on morale \\
c) Impacts on student learning \\
d) Effect of poor conditions on student achievement (page 11) \\
The most frequently cited negative effects (of poor working condi- \\
tions) were: \\
e) Absenteeism \\
f) Reduced levels of effort \\
g) Lowered effectiveness in the classroom \\
h) Lower morale \\
i) Reduced job satisfaction (page 11)
\end{tabular}

Table 5: Overall lack of available funds and/or unstable/absence of fixed funding source for facilities maintenance

\begin{tabular}{|c|c|}
\hline Source & Findings \\
\hline $\begin{array}{l}\text { Westerling, D., \& Poftak, } \\
\text { S. (2007). Our legacy of } \\
\text { neglect: The Longfellow } \\
\text { Bridge and the cost of de- } \\
\text { ferred maintenance. White } \\
\text { Paper, 40,1-36. }\end{array}$ & $\begin{array}{l}\text { We either fail to budget for maintenance, or discourage upkeep by } \\
\text { forcing state managers to fund maintenance out of annual operating } \\
\text { budgets (page 1). } \\
\text { There is no statewide plan in place to stop the problem from growing } \\
\text { worse. }\end{array}$ \\
\hline $\begin{array}{l}\text { Lawrence, B. K. (2003). Save } \\
\text { a penny, lose a school: The } \\
\text { real cost of deferred main- } \\
\text { tenance. Rural Trust Policy } \\
\text { Brief Series on Rural Educa- } \\
\text { tion }\end{array}$ & $\begin{array}{l}\text { - School districts across the nation are dedicating a smaller percent- } \\
\text { age of available funds to maintaining and operating the facilities that } \\
\text { house America's youth (from 9.0\% in } 1993 \text { to } 7.4 \% \text { in 2003) (page 7). } \\
\text { The deficit in maintenance spending is likely to get worse as federal } \\
\text { mandates for health and safety standards have absorbed money that } \\
\text { might have funded maintenance and renovations projects. } \\
\text { - Few states fund routine maintenance of school facilities, and instead } \\
\text { assign this essential responsibility to the local district. Few states even } \\
\text { support bonds for maintenance, leaving poor rural communities with } \\
\text { limited resources and few alternatives (page 12). } \\
\text { - Preventative routine maintenance can extend the life of any facility } \\
\text { and, therefore, is a good investment. Unfortunately, school districts on } \\
\text { average have decreased their investment in maintaining facilities (page } \\
\text { 7). }\end{array}$ \\
\hline
\end{tabular}


Table 5 (Continued): Overall lack of available funds and/or unstable/absence of fixed funding source for facilities maintenance

\begin{tabular}{|c|c|}
\hline Source & Findings \\
\hline $\begin{array}{l}\text { Carlson, S. (2008). As cam- } \\
\text { puses crumble, budgets are } \\
\text { crunched. The Chronicle of } \\
\text { Higher Education, } 37(15) \text {, } \\
\text { A1. }\end{array}$ & $\begin{array}{l}\text { - Donors don't typically want to put their names on pieces of sewer pipe, } \\
\text { so the un-glamourous, but very necessary maintenance money usually } \\
\text { comes out of the operations budget (page 2). }\end{array}$ \\
\hline $\begin{array}{l}\text { Hunter, R. C. (2009). The } \\
\text { public school infrastruc- } \\
\text { ture problem: Deteriorat- } \\
\text { ing buildings and deferred } \\
\text { maintenance. School Busi- } \\
\text { ness Affairs, 75(2), 10-14. }\end{array}$ & $\begin{array}{l}\text { - The condition of the district's buildings was a direct reflection of the } \\
\text { long-standing lack of community support, which was evidenced by the } \\
\text { community's refusal to approve a tax increase for } 25 \text { years (page 13). } \\
\text { The deterioration of public schools' buildings is more prevalent in } \\
\text { large cities because funding shortfalls have deferred maintenance, and } \\
\text { the cities now require huge sums to bring buildings up to acceptable } \\
\text { standards (page 12). } \\
\text { - In Kansas City, this was the case until the judge issued his order } \\
\text { (page13). } \\
\text { This district operated under the supervision of a federal court, which } \\
\text { ordered the development of a long-range capital improvement plan } \\
\text { (page 13). }\end{array}$ \\
\hline $\begin{array}{l}\text { State University System of } \\
\text { Florida (2012). Report to the } \\
\text { Florida Board of Governors. }\end{array}$ & $\begin{array}{l}\text { - "We have a crisis in infrastructure funding amid State University Sys- } \\
\text { tem institutions" (page 1). } \\
\text { - The State University System currently relies on state Public Education } \\
\text { Capital Outlay dollars--or "PECO"--as the primary source of both the } \\
\text { university construction and building maintenance. However, for the } \\
\text { past three years, PECO funding has seen dramatic reduction-- drop- } \\
\text { ping from \$600 million in } 2008 \text { to } \$ 7 \text { million today, and projected to } \\
\$ 0 \text { in } 2013 \text { (page 3). }\end{array}$ \\
\hline $\begin{array}{l}\text { Star Tribune (2007). Get } \\
\text { ready for higher infra- } \\
\text { structure costs; America's } \\
\text { deferred maintenance tab } \\
\text { runs into the trillions. The } \\
\text { Minneapolis Star Tribune. }\end{array}$ & $\begin{array}{l}\text { - China spends } 9 \text { percent, Japan } 10 \text { percent, and India } 3.5 \text { percent of } \\
\text { their gross domestic product on infrastructure. The comparable U.S. } \\
\text { figure is } 0.93 \text { percent. } \\
\text { - When it comes to infrastructure, America is more of a follower and no } \\
\text { longer a world leader. The United States is on the cusp of a crisis. } \\
\text { - When the nation's state transportation officials were asked in a survey } \\
\text { whether their infrastructure was capable of meeting state needs in the } \\
\text { next } 10 \text { years, } 83 \text { percent said, "No." }\end{array}$ \\
\hline $\begin{array}{l}\text { Schweers, J. (2016, January } \\
\text { 11). Florida public educa- } \\
\text { tion budget choice teach- } \\
\text { ers or buildings. Tribune/ } \\
\text { Naples Daily News Capital } \\
\text { Bureau. }\end{array}$ & $\begin{array}{l}\text { - "It's a zero sum game because we take money away from general reve- } \\
\text { nue, and it has to come from somewhere," said Senator Don Gaetz. }\end{array}$ \\
\hline $\begin{array}{l}\text { Postal, L. (2012, January } \\
\text { 13). Statewide shortfall like- } \\
\text { ly to halt school building } \\
\text { plans. Orlando Sentinel. }\end{array}$ & $\begin{array}{l}\text { - State officials do not yet know which project will be hurt because } \\
\text { money entering the Public Education Capital Outlay fund (PECO) has } \\
\text { dwindled and looks to keep dropping through } 2013 \text {. } \\
\text { - In Florida, } 67 \text { school districts received no PECO funds this year and } \\
\text { only limited allocations in the past few years, so they are likely to have } \\
\text { fewer project on their books relying on that pot of money. } \\
\text { - It has become necessary for difficult decisions to be made on which } \\
\text { projects may be funded and which must be discontinued at this point } \\
\text { in time," Gov. Rick Scott said in response to the } \$ 250 \text { million shortfall } \\
\text { in funding. }\end{array}$ \\
\hline
\end{tabular}


Table 5 (Continued): Overall lack of available funds and/or unstable/absence of fixed funding source for facilities maintenance

\begin{tabular}{|c|c|}
\hline Source & Findings \\
\hline $\begin{array}{l}\text { Postal, L. (2012, January } \\
\text { 13). Statewide shortfall } \\
\text { likely to halt school build- } \\
\text { ing plans. Orlando Sentinel. } \\
\text { (Continued) }\end{array}$ & $\begin{array}{l}\text { PECO raises money through taxes on utilities, then bonds most of it } \\
\text { and uses the proceeds to pay for school construction projects. But rev- } \\
\text { enues into the fund have declined to the point where the state cannot } \\
\text { issue new bonds. }\end{array}$ \\
\hline $\begin{array}{l}\text { GAO Reports. (2008, Octo- } \\
\text { ber). Federal real property: } \\
\text { Government's fiscal exposure } \\
\text { from repair and mainte- } \\
\text { nance backlogs is unclear. }\end{array}$ & $\begin{array}{l}\text { - We have to report that our nation's fiscal policy is on an unsustainable } \\
\text { course. }\end{array}$ \\
\hline $\begin{array}{l}\text { Dixon, M. (2013). Fund de- } \\
\text { cline puts universities in a } \\
\text { bind; Money from telecom- } \\
\text { munications and electricity } \\
\text { has shrunk recently. Florida } \\
\text { Times Union. }\end{array}$ & $\begin{array}{l}\text { - University presidents are asking lawmakers again for new ways to pay } \\
\text { for construction. } \\
\text { University and K-12 education projects are both funded by the Public } \\
\text { Education Capital Outlay (PECO) money, which is made up of taxes } \\
\text { on electricity and certain telecommunications. Those taxes have taken } \\
\text { a hit in recent years--in part because of increased electricity efficien- } \\
\text { cies, and the growth of the internet and prepaid cell phone plans, } \\
\text { which are not included. }\end{array}$ \\
\hline $\begin{array}{l}\text { Filardo, M. (2016). State } \\
\text { of our schools: America's } \\
\text { K-12 facilities 2016. Wash- } \\
\text { ington, DC: 21st Century } \\
\text { School Fund. }\end{array}$ & $\begin{array}{l}\text { Do states and districts have adequate operating funds for cleaning, } \\
\text { maintenance and repairs to ensure buildings and grounds are healthy } \\
\text { and safe (page 3)? } \\
\text { Because capital construction is largely financed by local school dis- } \\
\text { tricts, the poor lending climate and reluctance to burden taxpayers at } \\
\text { the recession had a striking impact on spending (page 16). } \\
\text { Additionally, while funding to support facilities M\&O combines local, } \\
\text { state, and federal sources--M\&O competes with other essential aspects } \\
\text { of school district operations, such as salaries and instructional equip- } \\
\text { ment, which also need to be paid for through the same general oper- } \\
\text { ating budget. Therefore, school districts, especially those low-wealth } \\
\text { districts that have not been able to spend needed capital constructions } \\
\text { funds to make major repairs to their buildings, are put in a position } \\
\text { where they must stretch their general operating funds to try to make } \\
\text { up the difference (page 18). } \\
\text { The federal government helped build the country's public education } \\
\text { infrastructure with funding through the Works Progress Administra- } \\
\text { tion in the 1930's and then again in the post-World War II era with } \\
\text { funding from the National Defense Education Act. But during the two } \\
\text { decades studied in this report--except for a \$1.2 billion emergency } \\
\text { school repair initiative in the } 2001 \text { federal budget directed to high- } \\
\text { need districts and public schools with high concentrations of Native } \\
\text { American students--the federal government provided virtually no } \\
\text { support for states and districts capital responsibilities for public K-12 } \\
\text { school facilities (page 20). } \\
\text { Industry facilities spending standards: } \\
\text { Current Replacement Value (CRV)-- these standards are derived } \\
\text { by estimating the lifespan of the facility and the cost to build a new } \\
\text { one (page 23). } \\
\text { A general industry standard for facility M\&O (all facilities, not just } \\
\text { schools) indicates that building owners should expect to spend a mini- } \\
\text { mum of } 2 \text { percent of the CRV annually (page } 23 \text { ). }\end{array}$ \\
\hline
\end{tabular}


Table 5 (Continued): Overall lack of available funds and/or unstable/absence of fixed funding source for facilities maintenance

\begin{tabular}{|c|c|}
\hline Source & Findings \\
\hline $\begin{array}{l}\text { Filardo, M. (2016). State } \\
\text { of our schools: America's } \\
\text { K-12 facilities 2016. Wash- } \\
\text { ington, DC: 21st Century } \\
\text { School Fund. (Continued) }\end{array}$ & $\begin{array}{l}\text { To systematically reduce the accumulation of deferred maintenance, } \\
\text { states and districts will have to spend at least an additional } 1 \text { percent of } \\
\text { CRV on deferred maintenance annually over the next } 10 \text { years in the } \\
\text { highest-needs schools. At the end of the } 10 \text { years, the steady level of } \\
\text { spending coupled with adequate capital renewals, would reduce the es- } \\
\text { timated deferred maintenance burden from } \$ 271 \text { billion to } \$ 81 \text { billion. } \\
\text { In order to fully resolve the backlog of deferred maintenance, further } \\
\text { investment beyond } 1 \text { percent of the CRV annually will be required } \\
\text { (page 23). } \\
\text { If we as a nation continue to rely primarily on the local property tax, } \\
\text { we cannot expect better results (page 29). } \\
\text { Many states have been working to find dedicated revenues to support } \\
\text { facilities in their local districts (page } 29 \text { ). } \\
\text { To more fully leverage public facilities investment, a new generation of } \\
\text { structures, funding streams, and partnerships will be needed. Lever- } \\
\text { aging these investments means finding ways to use land and building } \\
\text { assets to raise and save funds, such as public-private and public-public } \\
\text { development partnerships, revolving loan funds, social impact invest- } \\
\text { ing, and other scalable and sustainable financing solutions (page 30). }\end{array}$ \\
\hline $\begin{array}{l}\text { Millan, N. (2016). Rising } \\
\text { star in Texas. Building Op- } \\
\text { erating Management, 22-27. }\end{array}$ & $\begin{array}{l}\text { Houston is growing, but Houston is constrained by a city budget cap, } \\
\text { which puts a hard ceiling on the amount of revenue it can bring in } \\
\text { from its growing population. Like many other cities, it is currently } \\
\text { delaying with a looming pension crisis, and Minnix is acutely aware } \\
\text { that his budget is a public trust and every dollar must go to the greatest } \\
\text { good (page 25). }\end{array}$ \\
\hline
\end{tabular}

Table 6: Funds available for facilities maintenance are diverted to another use.

\begin{tabular}{|c|c|}
\hline Source & Findings \\
\hline $\begin{array}{l}\text { Filardo, Mary } \\
(2016) \text {. } \\
\text { State of Our } \\
\text { Schools: America's } \\
\text { K-12 Facilities } \\
2016\end{array}$ & $\begin{array}{l}\text { - It is important to note that investments in one area can have a major impact } \\
\text { elsewhere. For example: if a district does not undertake the cleaning or the re- } \\
\text { quired routing and preventative maintenance, then major building systems and } \\
\text { components will not last as long as designed. }\end{array}$ \\
\hline $\begin{array}{l}\text { Millan, N. (2016). } \\
\text { Rising star in } \\
\text { Texas. Building } \\
\text { Operating Man- } \\
\text { agement, 22-27. }\end{array}$ & 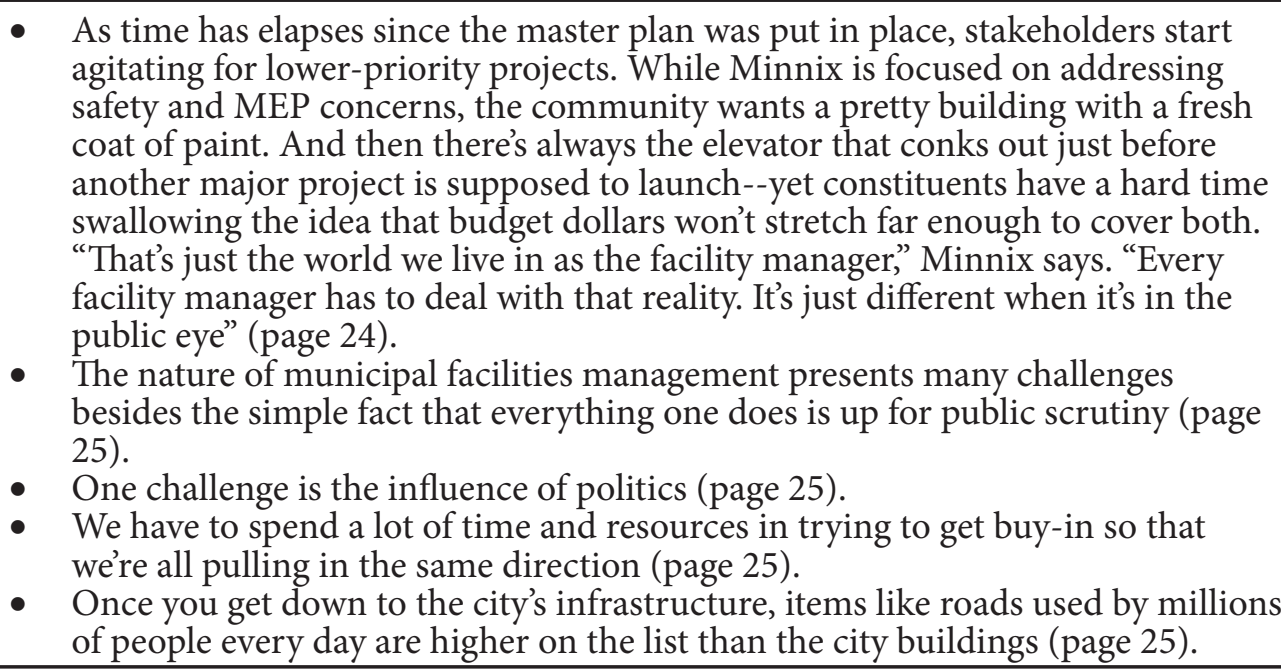 \\
\hline
\end{tabular}


Table 6 (Continued): Funds available for facilities maintenance are diverted to another use.

\begin{tabular}{|c|c|}
\hline Source & Findings \\
\hline $\begin{array}{l}\text { Hunter, R. C. } \\
\text { (2009). The public } \\
\text { school infrastruc- } \\
\text { ture problem: } \\
\text { Deteriorating } \\
\text { buildings and } \\
\text { deferred main- } \\
\text { tenance. School } \\
\text { Business Affairs, } \\
\text { 75(2), 10-14. }\end{array}$ & $\begin{array}{l}\text { - Our nation must take major steps now to address the school infrastructure } \\
\text { problem before it worsens. Clearly, it is easier to defer maintenance and to put } \\
\text { these problems off for future generations (page 14). }\end{array}$ \\
\hline
\end{tabular}

\section{Discussion}

The existing information regarding public facilities management and maintenance is somewhat telling. While there are nuances that differ between the various sectors of public facilities owners, there are many obstacles to efficiency and effectiveness that are shared.

As a result of studying the past and current industry data, individual themes have emerged that are common contributors to significant obstacles that challenge the success of facilities management. These obstacles are identified in Figure 1.

Each of these obstacles are widely discussed amongst those in the public sector facilities management industry. To that end, some have reported positive impact to their facilities program as they address these obstacles. Each of the issues are discussed:

\section{Decisions Made by Those Who Lack Ex- pertise}

Decisions are being made by those who lack expertise regarding the overall issues related to facilities management. Whether it is a county commission board, city council, state government, or an educational school board, chances are likely that there aren't construction or facilities experts on the board with a vote that drives asset management decisions. This situation creates a void where informed votes are essential. It is vital that continuing industry expertise be available to highlight the importance of facilities management and maintenance, and offerings from third party reports have not shown to have the necessary impact within the decision making arena. According to the information identified in this study, regardless of outside input from staff

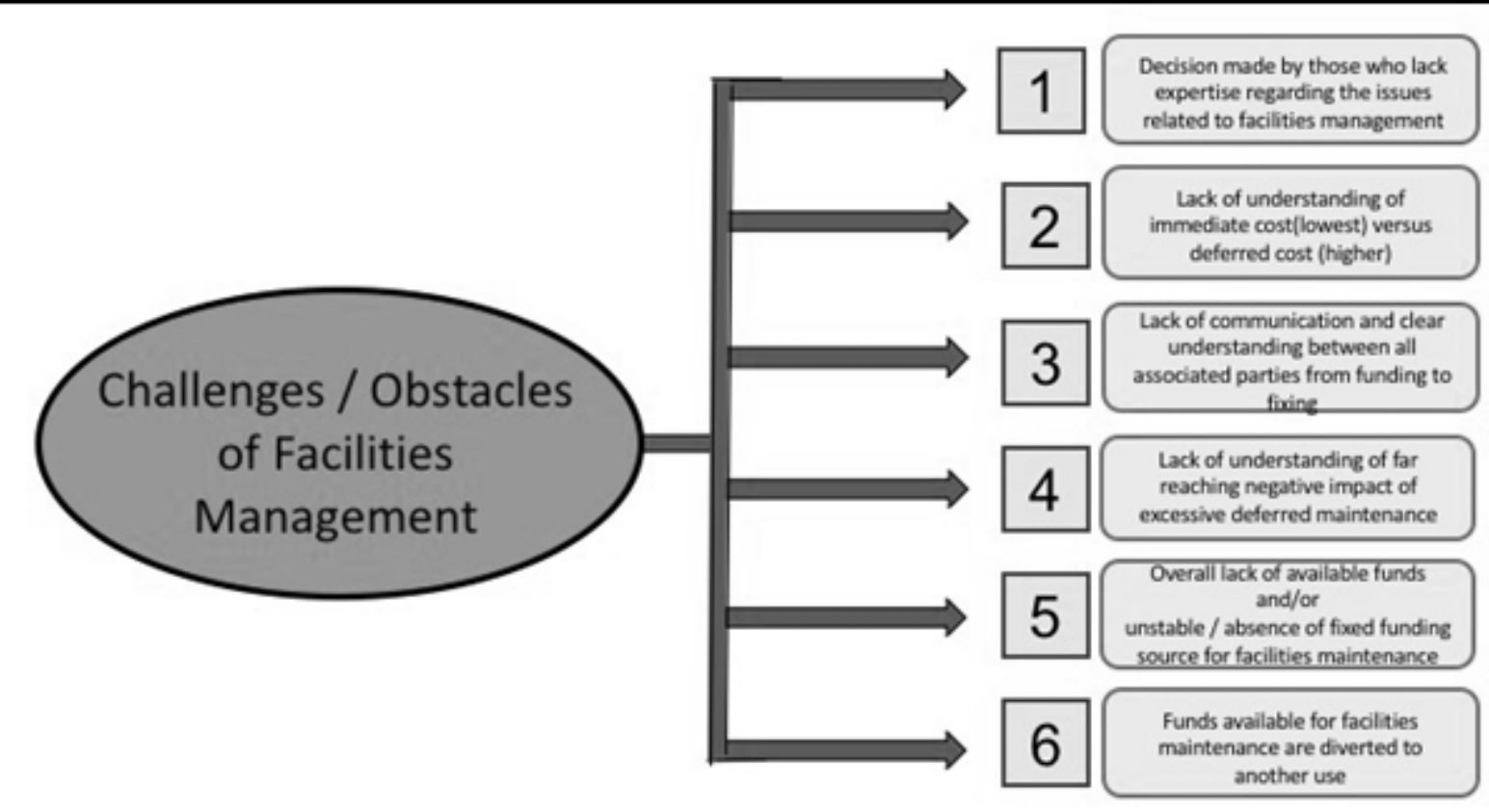

Figure 1: Challenges and Obstacles of Facilities Management 
or industry experts, based on their ultimate vote it appears that those members making the funding decision lack a clear understanding of the need to prioritize funding for their facilities maintenance.

As an example: An incoming director in one of our nation's largest cities, clearly understood the need to have complete support along with the votes from his leadership's hierarchy, and made it an early goal to educate his board to understand how critical a quality facilities management program was for their city. He knew that without their support, he would fail. Regardless of how effective his strategic plan was, he needed their vote and their financial support to execute it successfully.

The city of Houston's general services manager said it best when he noted that one of his biggest challenges is the influence of politics. Making constituents happy is the political mission of the board which may not align with the critical need of the city's facilities. In order to defend the needs of the city's facilities, he developed a plan that included a comprehensive presentation of the scope of work required throughout the city. He also prioritized, organized and made clear to them--his strategic plan. In other words, the manager understood the need to "teach" his bosses about facilities management, making them aware, and thus able to focus on the priority to maintain their facilities pro-actively with certain and consistent funding (Millan, 2016).

Another example cites the Longfellow Bridge which for decades suffered the results of the communities' leadership which, regardless of reports from the industry experts, deferred maintenance that ultimately sank to a level of crisis.

The state of Massachusetts suffered a devastating loss as a result of decisions made to defer maintenance of an aging bridge. It was noted that the postponement of routine maintenance hastened the failure of the bridge that was outwardly showing signs of age and distress. Frustration mounted as it became apparent that engineering reports describing the urgent maintenance needs had been solicited and presented to the governing body without resulting in the appropriate actions necessary to address the critical conditions of the bridge (Westerling \& Poftak, 2007).

Here is a bit of history that will illustrate a series of events that, to this day, is not unusual in the "political practices" of the public arena. The Longfellow Bridge was built in 1907 and was the center of great political fanfare. According to Westerling and Poftak (2007), "Festivities included a parade, an invitation-only lunch, a grandstand with 2,000 ticketed guests, a program of speeches and evening fire- works" (p. 5).

In 1959, fifty-two years after the political fan-fare, some areas of the bridge were reconstructed with decks of reinforced concrete. Decades later, in 2002, at the age of ninety-five the bridge underwent repairs. However, despite the needs cited in the engineering report, approximately one-third of the $\$ 3.2$ million repair was spent on non-structural issues including sidewalks, lighting and the removal of graffiti. The bridge was re-inspected again in 2006 which spawned a complete renovation which began in 2013, was scheduled to be completed in 2016, and is now projected to be completed no earlier than 2018. During the phase of investigation and thereafter, statements of frustration were made with regard to the absence of acting on a pro-active maintenance program for the bridge. This failure to act in a timely fashion is believed to have contributed to the catastrophic situation that is woefully over budget and years behind schedule (Westerling \& Poftak, 2007).

Westerling and Poftak (2007) stated that the deferral of maintenance was caused by a number of factors that included an "unwillingness to prioritize maintenance over new projects" as well as "political incentives that discourage spending on maintenance... The result is a wasteful shortening of service life, a dysfunctional asset construction scheme, and ultimately, diminished quality of life for the Commonwealth's citizens" (Westerling \&

Poftak, 2007, p. 5).

A model was created that showed how sustained investment would have reduced the overall cost of owning the Longfellow Bridge for the past hundred years. Along with the Longfellow Bridge, the community's other bridges shared the same critical needs. It has been reported that a $\$ 3$ billion accelerated bridge repair program has been put in place by the state. (Westerling \& Poftak, 2007)

Given the compelling argument that included reports from industry experts to prioritize the maintenance of their facilities, why did the governing body choose not to? Was it their lack of overall expertise regarding the issues that resulted in their inaction?

\section{Negative Impact of Deferred Cost to the Overall Facilities Program}

There is a lack of understanding of the negative impact to the overall facilities program between immediate cost (lowest) versus the deferred cost (higher). According to Westerling and Poftak (2007), "Our failure to maintain our assets has actually driven up infrastructure costs, as the risk of catastrophic fail- 
ure forces us to fund emergency repairs" (p. 30).

Thus, over the course of decades the governing board chose to defer the necessary maintenance on the Longfellow Bridge which, in hindsight, cost the citizens exponentially more money, not to mention the delays in commuting and the loss of productivity in all areas of the surrounding community. Westerling and Poftak (2007) state, "The postponement of routine maintenance maximizes the operating funds available in the current year, but also hastens the failure of capital assets. The eventual failure of the assets will result in an emergency disbursement of capital funds" (p. 1).

According to Westerling and Poftak (2007), "Deferred maintenance is the compounded effect of deferring maintenance from one year to the next, the cost of deferred maintenance in year one will increase significantly in every subsequent year" (p. 1). Studies have been conducted to establish a general guideline for the negative impact to facilities that are subject to chronic deferred maintenance. As an example, "DeSitter's law, 'law of fives', estimates that if maintenance is not performed, then repairs equaling five times the maintenance costs are required" (Westerling \& Poftak, 2007, p. 13).
Westerling and Poftak (2007) found, "People often use the phrase, 'pay me now or pay me later', but when it comes to deferred maintenance it needs to be changed to pay me now or pay me more later" ( $\mathrm{p}$. 15). Refer to Figure 2 to see the impact of deferred maintenance.

Given the well-documented, negative impacts that include increased cost associated with emergency repairs and poor basic facility conditions, it seems illogical that any governing body would allow excessive deferred maintenance to exist within their facilities. Could it be that those making the decision to defer maintenance simply don't understand the negative impact?

\section{Problems Ranging from "Funding to Fixing" the Facilities}

There is a lack of communication and clear understanding between all associated parties from "funding to fixing" the facilities. A pertinent question regarding these problems is: What would you do with a million dollars? Those words are inspiring. What a great way to begin the dream of lifting the fog created by obstacles that interrupt a quality facilities management program. Imagine if all your

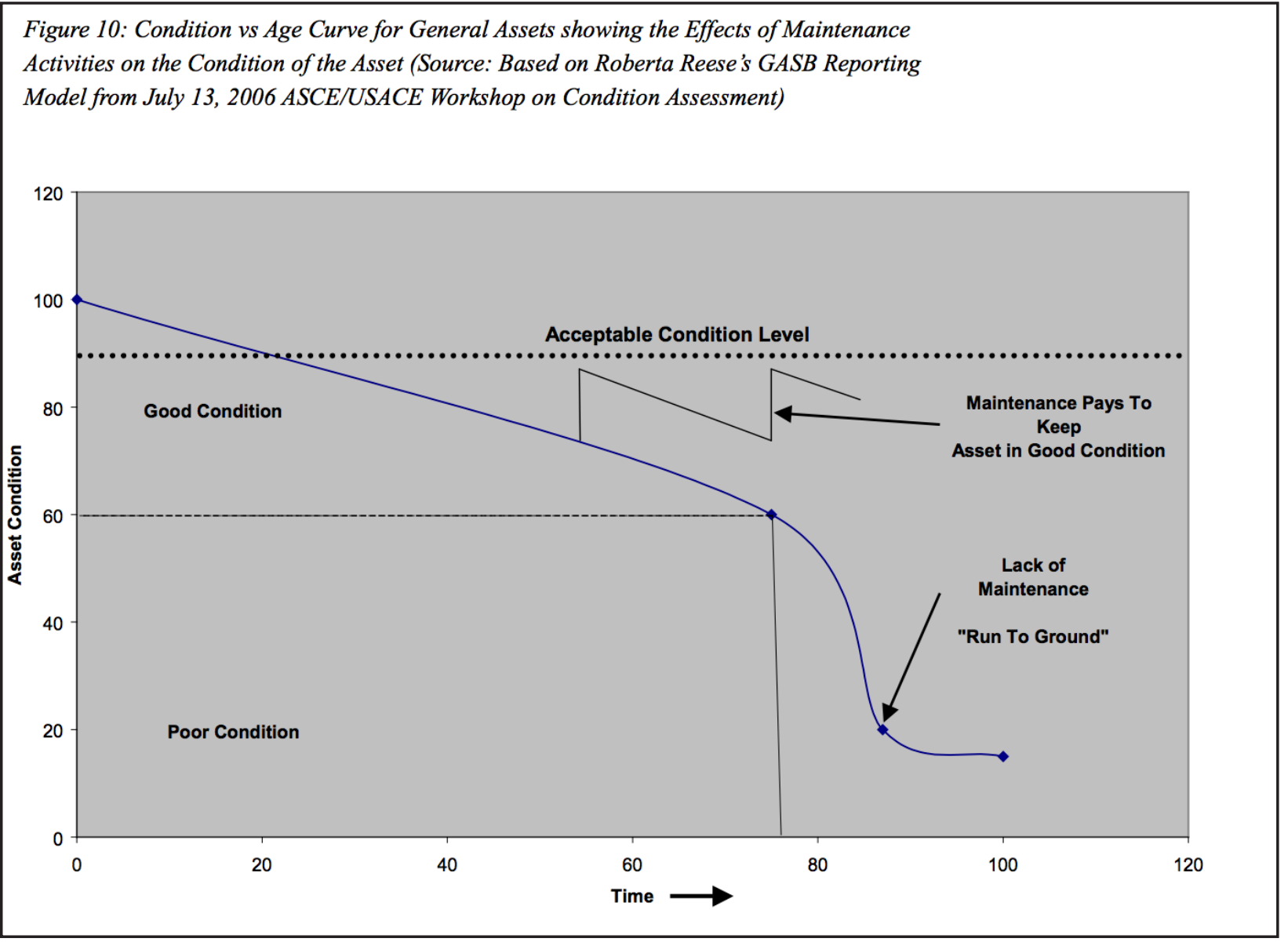

Figure 2: Deferred Maintenance Leads to Poor Condition of Assets 
obstacles were suspended for a moment, and you could focus on eliminating one of the most chronic problems (i.e., communication) that plagues most organizations--clear communication begets clear understanding of the issues across the entire team. It is no secret that miscommunication leads to failure. Stated overall goals aren't met because the individual's goals aren't aligned. Without question, poor communication results in the failure of the targeted mission.

According to Millan (2016), in Houston, Texas, when the question was asked of their incoming director of general services, "What would you do with a million dollars? ... he used the resources to perform an exhaustive assessment of every facility in the portfolio and create a facility condition index rating" (p. 22). Millan (2016) states the director found the city was in a highly reactive mode, responding to immediate building maintenance needs $96 \%$ of the time. The industry standard goal for building maintenance is $20 \%$ reactive and $80 \%$ pro-active. The challenge to gain control of the quality, cost, and liability was overwhelming. His decision was to use his million dollars to create a firm footing through an exhaustive facilities assessment.

This proved to be very successful as he moved forward. Not only did the assessment provide him with a clear understanding of the comprehensive needs, it provided a platform of data that became his basis of communica-

tion with the board, the very group of decision makers whose responsibility it is to support and fund his facilities program.

Communication and buy-in of the plan must include the full spectrum of participants in a facilities management hierarchy. Whether it be those who fund the program or those who ultimately fix the facilities, clear communication is critical. Each must understand the overall mission and their part in achieving the goal. Millan (2016) quotes the director who attributes, "Working closely with the mayor and a key council member, (he) helped to create a line item in the city's budget to address maintenance, renewal, and repair of municipal buildings" (p. 24). However, he also understood that in order to complete his mission successfully, he had to clearly communicate the goal to his staff and their workers. In summary, he made the comment, "I have to be really in tune to my people, but also be in tune to the political framework that runs this city and be able to share with them what exactly is going on. I have to stay consistent with that message and I have to do it on a regular basis" (Millan, 2016, p. 25).
Through the use of clear communication based on a data driven strategic program, the city of Houston was able to make great strides from $96 \%$ reactive work to $65-70 \%$ reactive work over the course of about five years. The director stated, "That plan has been driving the organization for the last five years. So now everybody in the organization has a clear direction on where we're trying to go" (Millan, 2016, p. 24).

In agreement, Carlson (2008) stated in a report, "The more specific or transparent you can be about stating your needs, whether it be a board of regents or a state department of administration, the more effective you will be at getting the funds you need" (p. A1).

A common theme indicates that clear communication of the facilities' needs is critical to successful facilities programs. Without complete understanding, governing boards may unknowingly make wrong decisions as they prioritize their budget allocations. The resulting lack of funds for maintenance may be attributable to a lack of clear communication that doesn't convey the need to those making the funding decisions. "Understanding the cost of deferred maintenance and being able to articulate that to the boards and committees that will take the next steps to obtain taxes, state help, and/or fundraising is essential for facilities administrators" (Payton-Jones, 2014, p. 15).

Could a lack of clear communication between all associated parties explain the decision to detrimentally deferred maintenance?

\section{Far-reaching Negative Impacts Due to Excessive Deferred Maintenance}

Within a failing facilities management program there are many levels of the operation that are affected. Certainly, the basic building quality becomes diminished, but beyond the accelerated decline of the asset's useful life, there are other measurable negative impacts.

First, there are additional resulting impacts from a failing facilities program that further exhaust underfunded budgets. For example: increased liability can become a costly result as lawsuits are filed for personal injuries that may be attributed to a poorly maintained facility and its surroundings. Not only is the cost of the litigation and the settlement claim unbudgeted, the exponentially higher cost of emergency repairs that result from the incident aren't budgeted either. The entire unscheduled expense takes precedent, thus creating a domino effect that draws money from other budgeted line items, leaving that 
previously funded work, deferred. This vicious cycle, once started, is difficult to turn around.

Further, there is the emotional and psychological impact that failing facilities create. The impact on educational facilities has been studied. Take public school facilities, for example. According to Lawrence (2003), "Deferring maintenance reduces air quality, causes breakdowns in infrastructure and mechanics and higher energy consumption which leaves even less money available for maintenance. The condition of poorly maintained facilities can affect the health and safety of children and adults who use them, as well as their morale and academic performance. The most frequently cited negative effects (of poor working conditions) were:

a) Absenteeism classroom

b) Reduced levels of effort

c) Lowered effectiveness in the

d) Lower morale

e)

Reduced job satisfaction" (Lawrence, 2003).

In stated agreement, Payton-Jones (2014) noted that, "There is a direct correlation between the condition and cleanliness of the school and grades, attitudes, absenteeism." Additionally, "The National Institute of Building Sciences did a study that shows that poor building conditions definitely negatively impact teaching and learning" (p. 14).

When the decision to chronically defer maintenance is made, is there consideration given to these and other far-reaching impact issues?

\section{Overall Lack of Funds and/or Unstable/ Absence of Fixed Funding Sources}

There is an overall lack of funds and/or unstable/ absence of fixed funding sources for facilities maintenance. As with all failures, a struggle to identify ground zero ensues. Whether the focus is city, county, state, federal, K-12 or university facilities programs, they all share a woeful report of lack of available funds.

Payton-Jones (2014) states, in 1996 a "study of facilities conditions at US college and universities estimated at that time that there was $\$ 26$ billion in accumulated deferred maintenance, $\$ 5.7$ billion of which pertained to urgent needs" (p. 13).

While according to Carlson (2008), in 2005, the American Society of Civil Engineers said, "Ameri- can infrastructure is in dire shape and estimated that the country needs to spend \$1.6-trillion to bring it up to good condition" (p. A1). In GAO Reports (2016), the GSA reported that, "at the end of 2015 it had over $\$ 1.2$ billion in deferred maintenance and repair work that was categorized as needing to be performed immediately to restore or maintain the building inventory in acceptable condition" (p. 1).

In Florida, the university and K-12 educational community relies heavily on PECO (public education capital outlay) funds for their capital outlay money. These funds are derived from two fixed utility sources, taxes on the land-line communication telephone system and taxes on electricity. Unfortunately, land-line telephones have become somewhat obsolete over the past years and electric consumption has decreased due to operating efficiencies. While each changing dynamic offers some benefit to our society, there is an unintended and devastating negative funding impact to the PECO fund. Postal (2012) stated that recently, in the state of Florida, Governor Rick Scott said, "It has become necessary for difficult decisions to be made on which projects may be funded and which must be discontinued at this point in time" (p. 1).

At that same time, the State University System of Florida (2012) states in a report to the Florida Board of Governors, "we have a crisis in infrastructure funding amid State University System institutions." Further reporting in the Florida Times Union by Dixon (2013) cited a drop from $\$ 600$ million in 2008 down to $\$ 7$ million in 2012 with a projection of $\$ 0$ in 2013. That same year, Dixon stated, "that with a dried-up source of money and an inventory of buildings in need of repair, university presidents are asking lawmakers again for new ways to pay for construction."

Currently, according to Lawrence (2013), there has been no resolution to the ever-growing need to increase the budgets to maintain our public assets. "Few states fund routine maintenance of school facilities, and instead assign this essential responsibility to the local district. Few states even support bonds for maintenance, leaving poor rural communities with limited resources and few alternatives" (p. 13).

Regardless of the fact that: "preventative routine maintenance can extend the life of any facility and therefore, a good investment," states feel justified in delegating the responsibility to the local level (Lawrence, 2013, p. 8). Lawrence (2013) continues, "Unfortunately, school districts on average have decreased their investment in maintaining facilities," leaving the facilities programs in an even more critical situation (p. 8). 
Further, the fixed sources of funding are not yielding the funds necessary in education, and both local and state tax based revenue is not able to meet the demand. Special tax assessments have been approved regionally responding to the outcry from their governing leaders. However, facilities management continues to move toward crisis conditions in many areas.

Circumstances have become so dire in some cases that in 2009, Hunter (2009) found the schools in Kansas City were in such disrepair that, "the district operated under the supervision of a federal court, which ordered the development of a long-range capital plan..." (p. 12).

In the face of having a solid facilities program that includes a data driven strategy and the systems in place to implement it--how can it possibly work if the funding just isn't available?

\section{Funds Available for Facilities Mainte- nance Are Diverted to Another Use}

Funds that are available for facilities maintenance are frequently diverted to another use. It is not uncommon to find that deferred maintenance is the result of diverted funding.

Those who are responsi-

ble to allocate funding for the facilities management program are often elected to office and feel compelled to act in the interest of politics rather than in the interest of their facilities.

Once again, the decision to defer the maintenance on the Longfellow Bridge came at a high price. Decades passed and countless millions of dollars flowed through their budgets while engineering reports requesting maintenance went unfunded. It wasn't until recently, when the community was forced to react in crisis mode, that emergency funding was put in place-- costing the tax payers exponentially more.

The attraction to divert facilities maintenance funds is clearly understood. The desire to build a new facility and celebrate its completion clearly outweighs the motivation to fix an un-glamourous underground sewer. Further, most people who are giving money to an institution want to fund new buildings, new discovery, or new programs (Carlson, 2008, p. A1).

Even in the face of a successful and impactful turnaround facilities program, redirecting funding earmarked for maintenance becomes a challenge. As discussed earlier, the city of Houston made great strides to gain control over their facilities program. Millan (2016) reported that "as time elapses since the master plan was put in place, stakeholders start agitating for lower-priority projects." While the facilities director continued to focus on the strategic plan that had clear priorities, Millan (2016) quotes the facilities director who states, "The community wants a pretty building with a fresh coat of paint." He continues, "constituents have a hard time swallowing the idea that budget dollars won't stretch far enough to cover both" (p. 24).

There are other considerations as well. In some cases, an abbreviated scope of work is approved while "extra funds" are diverted to another project. For example, Carlson (2008) states, "patching a water line might cost $\$ 10,000$, but replacing the same line would cost $\$ 900,000-$-the motivation to patch is driven by the realities of the budget" (p. A1). As a result, the informed request in the budget to replace a system may ultimately be funded for repair only. This simply delays the inevitable need, which becomes more critical as time passes.

When used to balance a budget against other-high priority needs, this temporary repair can be justified. However, when used for other lower level priority work, this decision can lead to a facilities program in crisis. If this practice becomes standard operating procedure, the potential to work under emergency funding circumstances exists. "It's a shell game-we are constantly moving money around, trying to deal with the latest crisis" (Carslon, 2008, p. A1).

\section{Conclusions}

Through the research conducted, we can bring forward an understanding of three basic questions:

1) Why is deferred maintenance allowed to occur?

2) How has deferred maintenance become a "standard practice" given the developing insurmountable backlog, higher costs of maintenance, greater risk and liability and the reduced useful life of the facility?

3) Is there hope for redirecting an asset portfolio that has a failing facilities management plan heading toward crisis?

The focus group of this study was public owners that held large asset portfolios including: cities, counties, universities, and K-12 districts. They were reviewed based on the commonality of being funded through tax revenue and controlled by public governing boards. This provided for similarities in the structure of the organization, the sourcing of funds, and the exposure to public activities. 


\section{Why Is Deferred Maintenance Allowed to Occur?}

Given the negative impacts of higher cost, increased liability, and a shorter useful life of their facilities, why would organizations choose to defer maintenance? Six common issues were identified that contribute to the problem of deferred maintenance:

1) Decisions are being made by those who lack expertise in the overall issues related to facilities management.

2) There is a lack of understanding of the negative impact to the overall facilities program between immediate cost (lowest), versus the deferred cost (higher).

3) There is a lack of communication and clear understanding between all associated parties from "funding to fixing" the facilities.

4) There are far-reaching negative impacts due to excessive deferred maintenance.

5) There exists an overall lack of funds and/or unstable/absence of fixed funding sources for facilities maintenance.

6) Funds that are available for facilities maintenance are diverted to another use.

Payton-Jones (2014)

notes, "not all deferred maintenance need is bad, but we want to be conscious about what we are deferring. For example, if a school is considering a major renovation it may make more sense to defer certain projects in order to get better life out of its systems" (p. 14).

In other words, a deliberate decision to defer maintenance on a facility as a pro-active response to a master plan can sometimes be the best choice. It is when chronic deferment is chosen as a reactionary plan that facilities management begins to creep out of control which is when the real challenge begins. Deferred maintenance carries forward the same needs but with even greater urgency and most probably higher cost.

\section{How Has Deferred Maintenance Be- come a Standard Practice?}

How has deferred maintenance become a "standard practice" given the developing insurmountable backlog, higher costs of maintenance, greater risk and liability, and the reduced useful life of the facility? Deferred maintenance suffers from a snowball effect. Once it begins, if not remedied in the near term, the money and effort to regain control of the assets grows to become insurmountable. As noted, deferred maintenance can be the result of any one or a combination of the issues above. What seems to be the inevitable end result in most cases, is a perpetual struggle for these public institutions to stay ahead of the facilities' needs, and prevent the assets from entering into a crisis state.

Funding plays a major role in the perpetuation of the practice of deferred maintenance. It seems that once the facilities reach a state of great disrepair the management enters into crisis mode, with a common outcry of "more money." Hence, the challenge of public institutions--the need for money is not always met with the granting of money. Public organizations are driven with funds that are tax based, even if bonded. Therefore, there is not a steady income upon which to forecast; in fact, the income fluctuates with the economy. On the other hand, public facilities are mostly used all year, every year, regardless of the economy, so the needs of the facilities remain constant. One can argue, as the buildings ages, the cost of ownership increases.

Westerling and Poftak (2007) state, "For any asset, it is expected that there is a 40 percent drop in quality over 75 percent of its lifetime, followed by a more precipitous drop in the final quarter of the asset's life" (p. 13).

To make matters even more challenging, Carlson (2008) states, "If (asset owners) can't support their existing buildings, yet continue adding new ones, they are operating in what the facilities industry calls, run to failure mode--in other words, running buildings into the ground" (p. A1).

Because of the evolution of facilities management programs that slip into the vicious cycle of owning buildings that are in disrepair, the costs of maintenance increases, liability increases, and the buildings useful life is shortened. The snowball effect hastens. According to Carlson (2008), "It's a shell game--we are constantly moving money around, trying to deal with the latest crisis. As bad as it is now, it truly is coming to a place where something has to give" (p. A1).

\section{Redirecting Asset Portfolios That Have Failing Facilities Management Plans}

Is there hope for redirecting an asset portfolio that has a failing facilities management plan heading toward crisis? There is hope. As a whole, the issue of a failed facilities management program is overwhelming, and out-paces the opportunity for rehabilitation. The sum of the problem must be broken into its parts, and a strategic plan needs to be established in order to affect change. With a strategic plan, the opportunity to create a more efficient and effective 
facilities management and maintenance program exists.

Within the literature reviewed, there were examples of facilities that were heading toward, or completely in crisis mode. Their turn-around was based on the development of a strategic plan founded on measured data, that was clearly communicated to all participating members of the entire team with full buy-in, and a strong commitment to disallow deviation from the plan. There must be a dedicated effort to resist all unnecessary expenditures, and stay

\section{References}

Carlson, S. (2008). As campuses crumble, budgets are crunched. The Chronicle of Higher Education, 37(15), A1.

Dixon, M. (2013). Fund decline puts universities in a bind; Money from telecommunications and electricity has shrunk recently. Florida Times Union.

Filardo, M. (2016). State of our schools: America's K-12 facilities 2016. Washington, DC: 21st Century School Fund.

GAO Reports. (2008, October). Federal real property: Government's fiscal exposure from repair and maintenance backlogs is unclear. Retrieved from: http://www.gao.gov/new.items/d0910.pdf

GAO Reports. (2016, March). Federal real property: GSA could better identify risks of unforeseen conditions in repair and alterations projects. Retrieved from: http://www.gao.gov/assets/680/675851.pdf

Hunter, R. C. (2009). The public school infrastructure problem: Deteriorating buildings and deferred maintenance. School Business Affairs, 75(2), 10-14.

Lawrence, B. K. (2003). Save a penny, lose a school: The real cost of deferred maintenance. Rural Trust Policy Brief Series on Rural Education.

Millan, N. (2016). Rising star in Texas. Building Operating Management, 22-27.

Payton-Jones, K. (2014). A matter of time: Perspectives on deferred maintenance. American School and University. Retrieved from: http://www.asumag.com/deferred-maintenance/matter-time-perspectives-deferred-maintenance

Postal, L. (2012, January 13). Statewide shortfall likely to halt school building plans. Orlando Sentinel. focused on accomplishing the goals set forth by the strategic plan.

There are, however, factors that can't be controlled-such as the obstacle of funding. The strategic plan must be designed to withstand such unforeseen conditions. However, in no way can the plan (with funds available) suffer alterations that result in the deferral of required facilities maintenance work. This is the very action that created the snowball that began to roll in the first place!

Retrieved from: http://articles.orlandosentinel. com/2012-01-13/features/os-school-construction-money-20120113 1 peco-funds-construction-contracts-school-construction-projects

Schweers, J. (2016, January 11). Florida public education budget choice teachers or buildings. Tribune/Naples Daily News Capital Bureau. Retrieved from: http://www.tbo.com/news/education/ florida-public-education-budget-choice-teachers-or-buildings-20160111/

State University System of Florida (2012). Report to the Florida Board of Governors. Retrieved from: http://www.flbog.edu/resources/publications/2012-13 accountability.php

Star Tribune (2007). Get ready for higher infrastructure costs; America's deferred maintenance tab runs into the trillions. The Minneapolis Star Tribune. Retrieved from: http://www.startribune. com/

Westerling, D., \& Poftak, S. (2007). Our legacy of neglect: The Longfellow Bridge and the cost of deferred maintenance. White Paper, 40, 1-36.

\section{Review}

This article was accepted under the constructive peer review option. For futher details, see the descriptions at:

http://mumabusinessreview.org/peer-review-options/

\section{Author}

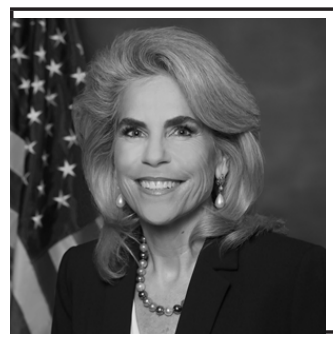

Rebecca Smith is president and founder of A.D. Morgan, a construction management and general contracting firm with offices in Tampa, Bradenton, and Lakeland, Fla. Smith and the company received the Ernst \& Young Entrepreneur of the Year Award for the State of Florida for the category of construction and real estate (1998). That same year, it received the Tampa Chamber of Commerce Small Business of the Year award. Smith earned a bachelor's degree in design architecture and a master's degree focusing on building construction from the University of Florida in Gainesville, Fla. She holds a Class A General Contractor's license. 